\title{
PEMANFAATAN AMPAS TEBU DALAM MENINGKATKAN PERTUMBUHAN JAMUR TIRAM PUTIH (Pleurotus ostreatus) DI KOTA PALEMBANG DAN SUMBANGSIHNYA PADA MATA PELAJARAN BIOLOGI DI SMA
}

\author{
Yustina Hapida $^{1 \text { a) }}$ \\ ${ }^{1)}$ Pendidikan Biologi Fakultas Ilmu Tarbiyah dan Keguruan UIN Raden Fatah Palembang, \\ Jl.Prof. K.H. Zainal Abidin Fikri No 1A KM 3.5, Palembang 30126, Indonesia \\ a)yustinahapida_uin@radenfatah.ac.id \\ Telp:+62852-7353-2397
}

\begin{abstract}
Sugar cane organic waste including biomass waste which has a high lignocellulose content, good for mycelium growth so that it can be used as a medium for the growth of Jamur Tiram Putih (Pleurotus ostreatus). This study aims to determine the amount of ampas tebu can increase the growth of Jamur Tiram Putih (Pleurotus ostreatus). The results of the studied Observation After $24^{\text {th }}$ day inoculated Jamur Tiram Putih (Pleurotus ostreatus), the addition of ampas tebu to the medium only affect the growth of mycelium. The dose of ampas tebu waste added to the medium are $150 \mathrm{gr}, 250 \mathrm{gr}$, and 350 gr. At $\mathrm{pH} 6,5$, temperatures range $22-25{ }^{\circ} \mathrm{C}$, humidity $72 \%$ and ampas tebu dose 350 gr can increased mycelium of Jamur Tiram Putih (Pleurotus ostreatus) growth.
\end{abstract}

Key words: Sugar cane waste, Jamur Tiram Putih, Pleurotus ostreatus

\begin{abstract}
ABSTRAK
Limbah Organik ampas tebu termasuk limbah biomassa yang mempunyai kandungan lignoselulosa yang tinggi, baik untuk pertumbuhan miselium, sehingga ampas tebu dapat dimanfaatkan sebagai media pertumbuhan Jamur Tiram Putih (Pleurotus ostreatus). Penelitian ini bertujuan untuk mengetahui takaran ampas tebu dapat meningkatkan pertumbuhan Jamur Tiram putih (Pleurotus ostreatus). Hasil penelitian menujukkan bahwa pengamatan hari ke-24 setelah diinokulasi bibit jamur Tiram putih (Pleurorus ostreatus), penambahan ampas tebu pada media hanya berpengaruh pada pertumbuhan miselium. Limbah ampas tebu yang ditambahkan pada media yaitu $150 \mathrm{gr}, 250 \mathrm{gr}$, dan 350 gr. Hasil Pengukukuran pH 6,5, suhu berkisar antara $22-25^{\circ} \mathrm{C}$, kelembaban $72 \%$. Jadi Takaran ampas tebu 350 gr yang dapat meningkatkan pertumbuhan miselium Jamur Tiram Putih (Pleurorus ostreatus).
\end{abstract}

Kata Kunci: ampas tebu, Jamur Tiram Putih, Pleurotus ostreatus

\section{PENDAHULUAN}

Jamur Tiram Putih (Pleurotus ostreatus) merupakan jamur pangan. Jamur ini telah lama dibudidayakan dan dijadikan sebagai salah satu bahan makanan alternatif karena mempunyai kandungan gizi yang tinggi dibandingkan dengan jamur lain. Kandungan Gizi jamur ini meliputi protein, lemak, fosfor, besi, thiamin dan riboflavin dengan komposisi terdiri dari $27 \%$ protein, 1,6\% lemak, 58\% karbohidrat, 11,5\% serat, 9,3\% abu dan 265 KKal. Mikroelemen yang bersifat logam sangat rendah sehingga aman dikonsumsi setiap hari. Selain kandungan gizi yang baik, jamur tiram putih (Pleurotus ostreatus) juga relatif tidak sulit untuk di tanam dan dibudidayakan karena syarat media untuk pertumbuhannya juga relatif mudah didapaatkan seperti serbuk kayu, dedak dan kapur dan sedikit air (Bakrun, 1997).

Budidaya jamur tiram putih di Indonesia masih relatif sedikit dibandingkan permintaan 
konsumen setiap hari. Prospek budidaya jamur tiram sangat cerah dan terbuka lebar asalkan kualitas dan kuantitas produk sesuai dengan persyaratan. Media tumbuh yang dapat digunakan sebagai alternatif budidaya jamur tiram dapat berasal dari limbah pertanian dan industri salah satu contohnya adalah limbah ampas tebu dan tahu (Sumarsih, 2015).

Di kota Palembang, budidaya Jamur Tiram Putih (Pleurotus ostreatus) masih terus dikembangkan, harga dan permintaan akan jamur ini masih relatif tinggi hingga saat ini produsen dalam pembudidyaan jamur tiram putih masih sangat sedikit yaitu sekitar 5 tempat yang masih melakukan kegiatan budidaya jamur tiram putih (Pleurotus ostreatus) dalam memenuhi permintaan rata-rata $85,85 \mathrm{~kg} /$ hari (Azmi dan Rahmi, 2014).

Syarat tumbuh jamur tiram putih (Pleurotus ostreatus) yaitu memerlukan sumber karbon yang berasal dari bahan organik untuk diuraikan menjadi senyawa karbon sederhana kemudian diserap masuk kedalam miselium. Miselium dan badan buah dapat berkembang pada bahan yang mengandung lignoselulosa, dengan nisbah $\mathrm{C} / \mathrm{N}$ 50-500. Bahan yang mempunyai nilai $\mathrm{C} / \mathrm{N}$ tinggi adalah kayu gergajian, bagas (ampas tebu), tongkol dan batang jagung, jerami, sekam, alang-alang, kertas, kayu gelondongan, limbah potongan kayu, kulit kacang-kacangan, ampas tahu (Sumarsih, 2015).

Ampas tebu termasuk limbah biomassa yang mempunyai kandungan lignoselulosa yang tinggi baik untuk pertumbuhan miselium. Ampas tebu mudah didapat dan memiliki unsur-unsur yang diperlukan jamur tiram putih untuk makan dan untuk meningkatkan kualitasnya. Kandungan ampas tebu berupa kadar air $52,67 \%, \mathrm{C}$ organik $55,89 \%$, $\mathrm{N}$ total $0,25 \%, \mathrm{P}_{2} \mathrm{O}_{5} 0,16 \%$ dan $\mathrm{K}_{2} \mathrm{O}$ $0,38 \%$. Ampas tebu memiliki kadar serat kasar dan kadar lignin yang sangat tinggi , masingmasing sebesar 46,5\% dan 14\% (Purwaningsih, 2014).

Masih terdapatnya kandungan dan gizi yang terdapat dalam ampas tebu, maka perlu adanya usaha untuk memanfaatkan limbah organik ini diantaranya sebagai bahan tambahan pada media pertumbuhan jamur tiram putih (Pleurotus ostreatus). Berdasarkan latar belakang di atas, maka perlu dilakukan penelitian

\section{METODOLOGI PENELITIAN}

\section{Waktu dan Tempat Penelitian}

Penelitian ini dilaksanakan selama satu yaitu bulan Agustus 2018 di Rumah Belajar Ceria dan Produksi Jamur Tiram Putih (Pleurorus ostreatus) Jl. H. Sarkowi B Kampung Sungai Pedado Keramasan Kertapati Palembang.

\section{Jenis Penelitian}

Jenis penelitian ini adalah penelitian kuantitatif dengan menggunakan metode eksperimen dengan mencampurkan ampas tebu dalam takaran yang berbeda dalam media pertumbuhan jamur Tiram Putih (Pleurotus ostreatus) rancangan percobaan menggunakan Rancangan Acak Lengkap (RAL) terdiri dari 4 perlakuan yaitu kontrol (tanpa ampas tebu), 150 gr, 250 gr dan 350 gr dan 6 ulangan.

\section{Prosedur Penelitian}

\section{Alat dan Bahan}

Alat yang digunakan adalah plastik, kertas saring, plastik tahan panas, ember, cincin (terbuat dari paralon), kapas, timbangan, alat sterilisasi, alat semprot, alat pengepres, rak tempat media, alat pengukur $\mathrm{pH}$, bunsen, ose, ayakan dan alat tulis.

Bahan yang digunakan adalah serbuk kayu, bekatul, ampas tebu, $\mathrm{CaCO}_{3}$, alkohol $70 \%$, air, spritus, gips dan bibit jamur tiram putih (Pleutorus ostreatus) F2.

\section{Cara Kerja}

\section{a. Pengeringan Ampas Tahu/Ampas Tebu}

Ampas tebu dikeringkan didalam oven atau dapat juga dijemur dibawah terik matahari secara langsung hingga benarbenar kering, setelah kering di blender dan didapatkan serbuk ampas tebu,

\section{b. Persiapan Media}

Serbuk kayu diayak terlebih dahulu agar dapat keseragaman ukuran yang baik. Bahan-bahan ditimbang seperti bekatul, serbuk kayu, $\mathrm{CaCO}_{3}$ dan ampas tebu yang sudah kering, ditimbang terlebih dahulu Bahan-bahan yang sudah disiapkan dicampur secara merata, agar pencampuran merata dilakukan pengadukan selama 1-2 jam, saat pengadukan ditambahkan sedikit demi sedikit air hingga semua bahan 
menggempal dan dapat dikepal tetapi tidak sampai meneteskan air. Pengomposan dilakukan dengan cara menutup rapat-rapat bahan yang sudah diaduk selama 1-2 hari.

\section{c. Pengisian Media}

Pengisian media tanam menggunakan plastik tahan panas dengan ukuran $2 \mathrm{~kg}$. Bahan yang sudah dikomposkan dimasukan kedalam plastik, pada saat pengisian media dipadatkan menggunakan kayu pemadat atau mesin pengepres, dalam setiap media harus memiliki berat 1200 gram. Media yang telah dipadatkan diberi cincin pada bagian leher plastik kemudian ditutup dengan plastik dan diikat dengan karet gelang, jika ada gunakan penutup ring.

\section{d. Sterilisasi}

Media atau baglog disterilisasi. Sterilisasi dilakukan menggunakan drum dengan suhu $80-90^{\circ} \mathrm{C}$ selama 6-8 jam kemudian media yang sudah disterilisasi didinginkan selama $1 \quad$ x 24 jam. Pendinginan dilakukan agar bibit jamur tiram putih tidak mati ketika ditanam

\section{e. Inokulasi (Penanaman bibit jamur tiram putih)}

Inokulasi (penanaman bibit jamur tiram putih) dilakuakan diruangan yang steril dengan menggunakan alkohol $70 \%$. Adapun cara menginokulasi yaitu : Mensterilkan tangan menggunakan alkohol $70 \%$, memanaskan ose diatas bunsen, membuka tutup baglog dan memanaskan ujung baglog sebelum di tanam dan botol bibit jamur di atas bunseen untuk menghindari kontaminasi, mengambil bibit jamur dengan ose memindahkannya kedalam baglog media tanam dan menutup baglog dan botol bibit dengan tutup sebelumnya yang sudah dipanaskan diatas api Bunsen

\section{f. Inkubasi}

Inkubasi merupakan masa pertumbuhan miselium hingga memenuhi media secara merata. Masa inkubasi biasanya berlangsung selama 30-45 hari.Inkubasi dilakukan dengan cara menyimpan media yang telah diisi dengan bibit pada kondisi tertentu agar miselia jamur dapat tumbuh, kemudian Baglog ditempatkan dirak, dan dibiarkan sampai tumbuh miselium.Kondisi ruangan inkubasi suhunya tidak boleh terlalu tinggi, jika suhu terlalu tinggi dapat dilakukan dengan cara memberikan sirkulasi udara atau menyiram lingkuan dengan air untuk mengurangi tingginya suhu.

\section{g. Pemeliharaan}

Pada massa pemeliharaan, bagian atas baglog dibuka sebagai tempat keluarnya tubuh buah jamur. Pemeliharaan dapat dilakukan dengan cara menyiram tanaman jamur sebanyak $3 x$ dalam sehari hal ini untuk menghindari hama dan penyakit dalam budidaya jamur tiram dilakuakan dari mulai pembuatan media, tempat atau lokasi dengan kondisi steril atau lokasi yang bersih dari kontaminan seperti serangga, binatang pengerat, mikroba dan senyawa-senyawa berbahaya

\section{h. Panen}

Setelah 5-10 hari penutup baglog dibuka, tubuh buah jamur sudah tumbuh. Selang 3-4 hari setelah primodia tubuh buah tumbuh, jamur telah siap dipanen

\section{i. Pengamatan}

Pengamatan dilakukan pada pertumbuhan jamur tiram pada masingmasing media yang telah dicampur dengan ampas tebu kemudian dilihat perbandingan pertumbuhannya, adapun parameter pertumbuhan yang diamati adalah sebagai berikut:

\section{- Panjang tangkai tubuh buah}

Dengan cara mengukur tubuh buah terpanjang, yaitu diukur pada pangkal tangkai sampai bagian bawah tudung buah jamur, pengukuran dilakukan pada akhir penelitian.

\section{- Diameter tudung buah}

Dengan cara mengukur tudung buah jamur yang terbesar, yaitu diukur pada pangkal tudung buah jamur sampai 
ujung tudung buah jamur, pengukuran dilakukan pada akhir penelitian.

- Berat basah tubuh buah jamur

Berat basah untuk setiap perlakuan diukur pada akhir penelitian dengan menggunakan timbangan.

- Jumlah tubuh buah jamur

Jumlah tubuh buah jamur untuk setiap perlakuan dihitung pada saat akhir penelitian dengan menghitung setiap tubuh buah jamur.

\section{Teknik Analisa Data}

Data yang dikumpulkan, dianalisis dengan uji $F$. adalah untuk mengetahui ada atau tidaknya pengaruh setiap takaran, setelah terdapat pengaruh dilakukan uji lanjut Duncan. Kemudian dilakukan perbandingan antara kedua media.

\section{HASIL DAN PEMBAHASAN}

\section{Hasil}

Tabel 1. Hasil Analisa Data Pertumbuhan Jamur Tiram Putih (miselium) pada media Ampas Tebu

\begin{tabular}{ccc}
\hline Perlakuan & Sampel & Rerata \\
& & \\
\hline P0 & 48 & 2,4646 \\
\hline P1 & 48 & 3,5375 \\
\hline P2 & 48 & 5,4271 \\
\hline Total & 48 & 9,5708 \\
\hline
\end{tabular}

Tabel 2. Hasil analisis Uji F data pertumbuhan (miselum) Jamur Tiram Putih pada media ampas tebu

\begin{tabular}{l|l|c|c|c|c}
\hline \multicolumn{7}{c}{ ANOVA } \\
\hline & $\begin{array}{l}\text { Sum of } \\
\text { Squares }\end{array}$ & Df & Mean Square & F & \multicolumn{1}{c}{ Sig. } \\
\hline Between Groups & 1410,824 & 3 & 470,275 & 20,572 &, 000 \\
\hline Within Groups & 4297,736 & 188 & 22,860 & & \\
\hline Total & 5708,560 & 191 & & & \\
\hline
\end{tabular}




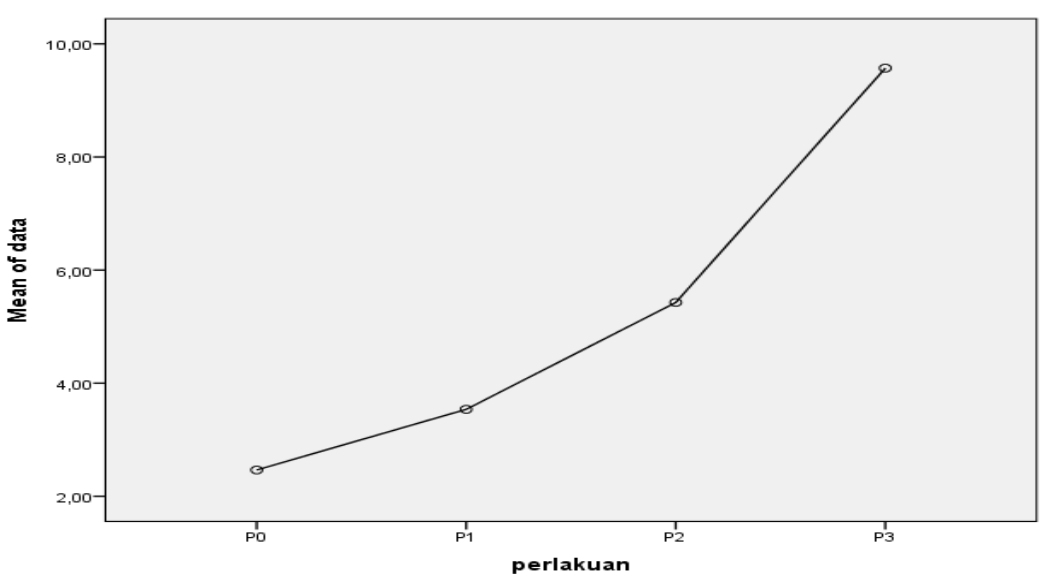

Gambar 1. Grafik Pertumbuhan Miselium Jamur Tiram Putih pada Ampas Tebu

\section{Pembahasan}

Dari hasil penelitian di dapatkan bahwa media ampas tebu pada penelitian ini dapat memacu pertumbuhan dari miselium jamur tiram putih disebabkan karena media yang diberikan untuk pertumbuhan jamur tiram putih (Pleurotus ostreatus) dapat memenuhi kebutuhan yaitu terdiri dari serbuk gergaji, dedak/bekatul dan kapur serta suhu pertumbuhan optimum yaitu $22-25^{\circ} \mathrm{C}$ hal ini sejalan dengan penelitian Sagala et al, (2015) menyatakan bahwa media bibit tanam jamur tiram berupa campuran dedak, gergaji dan air. Keberhasilan tumbuh jamur tiram tinggi karena suhu yang digunakan pada tempat penyimpanan bibit tanam merupakan suhu optimum berada pada $25-29{ }^{0} \mathrm{C}$ untuk budidaya. Menurut Pelczar and Chan, 2008, Golongan Cendawan dapat tumbuh dalam kisaran suhu yang luas, dengan suhu optimum bagi kebanyakan spesies saprofitik dari 22 sampai $\quad 30^{\circ} \mathrm{C}$, cendawan mampu memanfaatkan berbagai macam bahan untuk gizinya, namun cendawan juga adalah heterotrof. Karbon harus berasal dari sumber organik.

Penambahan media ampas tebu pada media tanam diduga dapat memenuhi kebutuhan lignoselulosa yang terdapat dalam serbuk gergaji dan ampas tebu. Sejalan dengan penelitian Pramitha dan Andini (2013) tentang pengaruh ampas tebu sebagai media pertumbuhan terhadap jamur tiram menyatakan bahwa media tanam ampas tebu dapat mempengaruhi kecepatan pertumbuhan jamur tiram dan berpengaruh terhadap kualitas fisik serta kandungan nutrisi jamur tiram. Hasil penelitian (Sulistyowati dan Purnomo (2014) pemberian ampas tebu sebagai media pertumbuhan jamur Tiram menunjukkan hasil jamur tiram yang dihasilkan memiliki nilai angka kecukupan gizi (AKG) dan batas ambang toleransi konsumsi mineral, pada variasi $25 \%$ menunjukan yang memiliki kadar kandungan terbaik dan am an dalam tubuh jamur tiram yakni kalium sebesar $15745 \mathrm{mg} / \mathrm{kg}, 240 \mathrm{mg} / \mathrm{kg}$ magnesium, 1290 $\mathrm{mg} / \mathrm{kg}$ mineral fosfor, $917 \mathrm{mg} / \mathrm{kg}$ natrium, $9605 \mathrm{mg} / \mathrm{kg}$ kalsium, $5606 \mathrm{mg} / \mathrm{kg}$ besi, dan $14,01 \mathrm{mg} / \mathrm{kg}$ mineral

Pertumbuhan miselium yang lebih baik pada media ampas tebu diduga karena pada ampas tebu masih terdapat molase yang merupakan nutrisi bagi pertumbuhan jamur tiram. Sejalan dengan pendapat Stevani (2011) menyatakan bahwa Salah satu indusri pangan yang menghasilkan limbah adalah industri gula tebu. Industri pengolahan gula tebu dari batang tebu menjadi gula pasir menghasilkan tetes tebu (molase). Molase diperoleh dari tahapan pemisahan kristal gula dan masih mengandung gula 50-60\%, asam amino dan mineral yang dapat dimanfaatkan sebagai bahan nutrisi tambahan pada pertumbuhan jamur tiram putih.

Hidayah dkk (2017) mengungkapkan bahwa jamur tiram mempunyai enzim lignoselulosa yang mampu merombak selulosa, lignin dan polisakarida lainnya, perombakan tersebut menghasilkan glukosa sebagai sumber karbonnya. Masih tersedianya asam amino yang ada pada ampas tebu tersebut diduga mempengaruhi pertumbuhan miselium dan kemunculan primordia lebih cepat yang akan berkembang menjadi tangkai dan tudung jamur, semakin besar diameter tudung akan menyebabkan berat basah jamur semakin tinggi. 
(2014) ada beberapa faktor yang mempengaruhi pertumbuhan mikroba dalam pangan salah satunya adalah faktor intrinsik pangan termasuk di dalam nya adalah nutrisi, faktor tumbuh, dan penghambat atau antimikroba, $\mathrm{pH}$, potensi oksidasi-reduksi yang memberikan efek terhadap pertumbuhan mikroba dalam kombinasi positif maupun negatif. Faktor Ekstrinsik termasuk di dalamnya adalah suhu dan kelembaban.

\section{Sumbangsih Penelitian Mata Pelajaran Biologi di SMA}

Penelitian ini akan di sumbangsihkan dalam materi pengayaan di kelas $\mathrm{X}$ pada pokok bahasan Jamur Fungi.

\section{KESIMPULAN}

1. Pemanfaatan Ampas Tebu dapat memacu pertumbuhan miselium jamur Tiram Putih (Pleurotus ostreatus) dalam waktu 24 hari setelah inkubasi

2. Takaran pemberian ampas tebu dalam media pertumbuhan jamur tiram putih yang dapat meningkatkan pertumbuhan miselium dalam penelitian ini pada takaran tertinggi yaitu 350 gr.

\section{UCAPAN TERIMA KASIH}

Penulis ucapkan terimakasih kepada semua pihak yang telah membantu dan memberikan dukungan secara penuh dalam kegiatan penelitian ini.

\section{DAFTAR PUSTAKA}

AzmiI, Nur; Hidayati, Rahmi. Analisis Tingkat Permintaan Jamur Tiram Pasar Tradisional dan Supermarket di Kota Palembang. Jurnal Ilmiah Agriba, 2014, 2.8.

Bakrun, M. C. YA, M. (1997).Jamur Tiram (Pembibitan, Pembudidayaan, Analisis Usaha). Jakarta: Penebar Swadaya.

Hidayah N, Tambaru, E. Abdullah, A. 2017. Potensi Ampas Tebu sebagai Media Tanam Jamur Tiram Pleurotus sp:
Departemen Biologi, FMIPA, Universitas Hasanuddin, Makassar. Jurnal Biologi Makassar, 2(2):28-38.

Pelczar, M.J dan E.C.S Chan. 2008. Dasardasar Mikrobiologi jilid I. Jakarta: UI Press.

Pramitha, E.S. dan Andini. 2013. Pemanfaatan Ampas Tebu Sebagai Media Pertumbuhan Alternatif Pada Budidaya Jamur Tiram (Pleurotus ostreatus). ITS. Surabaya. Jurnal Seni dan Sains Vol.2, No.1.

Purwaningsih, Ch. E. (2014). Pertumbuhan dan Produktivitas Jamur Tiram Putih (Pleurotus ostreatus) Pada Media Tumbu Limbah Blotong dan Ampas Tebu dengan Tambahan Bekatul. Madiun: Program Studi Biologi. 178181.

Sagala, Aprilina, Sonip, Risanti dan Irzaman. 2015. Penumbuhan Miselium Jamur Putih (Pleurotus ostreotus) Pada Media Sorgum dan Analisis Fourier Transform Infrared (FTIR). Prosiding Seminar Nasional Fisika Volume 4 Oktober 2015.

Sopandi, T dan Wardah. 2014.Mikrobiologi Pangan Teori dan Praktik.Maya(ed). Yogjakarta:ANDI Yogyakarta

Steviani, S., 2011. Pengaruh Campuran Media Tanam Serbuk Sabut Kelapa dan Ampas Tahu Terhadap Diameter Tudung dan Berat Basah Jamur Tiram (Pleurotus ostreatus). Skripsi. Fakultas Pertanian Universitas Sebelas Maret. Surakarta.

Sumarsih, Sri.(2015). Bisnis Bibit Jamur Tiram. Jakarta : Penebar Swadaya. 